\title{
Efficient synthesis of chloro-derivatives of sialosyllactosylceramide, and their enhanced inhibitory effect on epidermal growth factor receptor activation
}

\author{
NAGAKO KAWASHIMA ${ }^{1 *}$, HUANHUAN QU ${ }^{2,3^{*}}$, MARLIN LOBATON $^{1 *}$, ZHENYUAN ZHU $^{2}$, \\ MATTHIEU SOLLOGOUB ${ }^{2}$, WEBSTER K. CAVENEE $^{4}$, KAZUKO HANDA ${ }^{1}$, \\ SEN-ITIROH HAKOMORI ${ }^{1,5}$ and YONGMIN ZHANG ${ }^{2,6}$
}

\author{
${ }^{1}$ Division of Biomembrane Research, Pacific Northwest Research Institute, Seattle, WA 98122, USA; \\ ${ }^{2}$ Institute of Paris Molecular Chemistry, University Pierre \& Marie Curie Paris 6, Paris 75005, France; \\ ${ }^{3}$ Glycochemistry and Glycobiology Lab, Shanghai Institute of Materia Medica, Chinese Academy of Sciences, \\ Pudong, Shanghai 201203, P.R. China; ${ }^{4}$ Ludwig Institute for Cancer Research, University of California, \\ San Diego, La Jolla, CA 92093; ${ }^{5}$ Departments of Pathobiology and Global Health, University of Washington, \\ Seattle, WA 98195, USA; ${ }^{6}$ Institute for Interdisciplinary Research, Jianghan University, \\ Wuhan Economic and Technological Development Zone, Wuhan, Hubei 430056, P.R. China
}

Received July 8, 2013; Accepted January 23, 2014

DOI: $10.3892 / 01.2014 .1887$

\begin{abstract}
Glycosphingolipids are components of essentially all mammalian cell membranes and are involved in a variety of significant cellular functions, including proliferation, adhesion, motility and differentiation. Sialosyllactosylceramide (GM3) is known to inhibit the activation of epidermal growth factor receptor (EGFR). In the present study, an efficient method for the total chemical synthesis of monochloro- and dichloro-derivatives of the sialosyl residue of GM3 was developed. The structures of the synthesized compounds were fully characterized by high-resolution mass spectrometry
\end{abstract}

Correspondence to: Professor Sen-Itiroh Hakomori, Division of Biomembrane Research, Pacific Northwest Research Institute, 720 Broadway, Seattle, WA 98122, USA

E-mail: hakomori@u.washington.edu

Dr Yongmin Zhang, Institute of Paris Molecular Chemistry, CNRS UMR 8232, University Pierre \& Marie Curie Paris 6, 4 Place Jussieu, Paris 75005, France

E-mail: yongmin.zhang@upmc.fr

${ }^{*}$ Contributed equally

Abbreviations: DMEM, Dulbecco's modified Eagle's medium; GSL, glycosphingolipid; EGF, epidermal growth factor; EGFR, epidermal growth factor receptor; GM3, sialosyllactosylceramide; HRMS, high-resolution mass spectrometry; NMR, nuclear magnetic resonance; PBS, phosphate-buffered saline; r.t., room temperature; TBS, Tris-buffered saline

Key words: glycosphingolipids, GM3, chloro-derivatives of GM3, EGFR activation, cell proliferation, EGFR inhibitors and nuclear magnetic resonance. In analyses of EGFR autophosphorylation and cell proliferation $\left(\left[{ }^{3} \mathrm{H}\right]\right.$-thymidine incorporation) in human epidermoid carcinoma A431 cells, two chloro-derivatives exhibited stronger inhibitory effects than GM3 on EGFR activity. Monochloro-GM3, but not GM3 or dichloro-GM3, showed a significant inhibitory effect on $\triangle E G F R$, a splicing variant of EGFR that lacks exons 2-7 and is often found in human glioblastomas. The chemical synthesis of other GM3 derivatives using approaches similar to those described in the present study, has the potential to create more potent EGFR inhibitors to block cell growth or motility of a variety of types of cancer that express either wild-type EGFR or $\triangle \mathrm{EGFR}$.

\section{Introduction}

Glycosyl structures, expressed as either glycoproteins or glycosphingolipids (GSLs), are involved in a variety of cell functions. Gangliosides (GSLs containing sialic acid) are abundantly expressed at the membranes of mammalian cells, particularly neuronal cells. The expression profiles of gangliosides and other GSLs have been shown to change during cell differentiation, proliferation and oncogenic transformation (1). The ganglioside sialosyllactosylceramide (GM3; NeuAc $\alpha 3$ Gal $\beta 4$ Glc $\beta 1$ Cer) inhibits the activity of various growth factor receptor (GFR)-associated tyrosine kinases. For example, the exogenous addition of GM3 has been shown to inhibit BHK cell growth induced by fibroblast growth factor (2) and the phosphorylation of platelet-derived GFR (3) and epidermal GFR (EGFR) (4). EGF-induced EGFR activation in human epidermoid carcinoma A431 cells was shown to be strongly inhibited by GM3, but to a much lesser degree by various other gangliosides and neutral GSLs. The order of inhibition was GM3>>GM2, GD3, GM4>GM1, GD1a, 
GD1b, GT1b, GD2, GQ1b>lactosyl-Cer (5). The inhibition of cell proliferation by exogenously added GM3 has also been reported $(6,7)$.

In our previous preliminary study, it was found that fully halogenated GM3, starting from $N$-glycolyl-GM3, but not from $N$-acetyl-GM3, enhanced contact inhibition of tumor cell growth (8), indicating the possibility that the inhibitory effect of halogenated GM3 derivatives on EGFR activation is stronger than that of GM3 itself. The present study describes: (i) The complete chemical synthesis of monochloro-acetyl-GM3 and dichloro-acetyl-GM3 (referred to hereafter as monochloro-GM3 and dichloro-GM3, respectively), and (ii) evidence that these derivatives show stronger inhibitory effects in comparison with GM3, on the activation of EGFR and of $\triangle E G F R$, a common mutant detected in cancers $(9,10)$. The findings of the present study indicate the potential application of halogenated GM3 derivatives as a novel approach for cancer therapy.

\section{Materials and methods}

Synthesis of GM3 chloro-derivatives. All chemicals were reagent grade and used without further purification. Solvent ratios are by volume.

Dichloromethane $\left(\mathrm{CH}_{2} \mathrm{Cl}_{2}\right)$ was freshly distilled from $\mathrm{P}_{2} \mathrm{O}_{5}$. GM3 was synthesized as described previously (11) at the Institute of Paris Molecular Chemistry (University Pierre \& Marie Curie Paris 6, Paris, France). Nuclear magnetic resonance (NMR) spectra were recorded with a Bruker DRX 400 spectrometer $\left(400 \mathrm{MHz}\right.$ for ${ }^{1} \mathrm{H}$ NMR and $100 \mathrm{MHz}$ for ${ }^{13} \mathrm{C}$ NMR; Bruker, Fällanden, Switzerland). The chemical shifts were referenced to the solvent peaks; $\delta=3.31 \mathrm{ppm}\left({ }^{1} \mathrm{H}\right)$ and $\delta=49.00 \mathrm{ppm}\left({ }^{13} \mathrm{C}\right)$ for $\mathrm{CD}_{3} \mathrm{OD}$. The coupling constants were provided in Hz. High-resolution mass spectra (HRMS) were recorded with a Bruker micrOTOF spectrometer in electrospray ionization (ESI) mode, using the Tuning-Mix as a reference (Bruker). Reactions were monitored by thin-layer chromatography on glass plates precoated with silica gel $60 \mathrm{~F}_{254}$ (Merck, Darmstadt, Germany) and detected by charring with sulfuric acid. Flash column chromatography was performed on silica gel 60 (230-400 mesh; Merck).

GM3 (30 mg, $0.025 \mathrm{mmol})$ in $10 \mathrm{ml} 0.1 \mathrm{M} \mathrm{KOH}$ in $\mathrm{H}_{2} \mathrm{O} /$ butanol (1:9) solution was stirred at $80^{\circ} \mathrm{C}$ for $5 \mathrm{~h}$. The mixture was neutralized by $6 \mathrm{M} \mathrm{HCl}(12-14)$ and concentrated in vacuo. The resulting residue was purified by flash column chromatography $\left(\mathrm{CHCl}_{3} / \mathrm{MeOH}, 2: 1\right)$ to yield crude intermediate 3 (Fig. 1). To a solution of crude intermediate 3 (in $3 \mathrm{ml}$

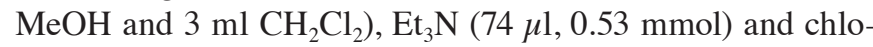
roacetyl chloride $(40 \mu 1,0.50 \mathrm{mmol})$ were added. The mixture was stirred at room temperature (r.t). for $2 \mathrm{~h}$ and concentrated in vасио. The resulting residue was purified by flash column chromatography $\left(\mathrm{CHCl}_{3} / \mathrm{MeOH}, 3: 1\right)$ to produce compound 1 . Compound 2 was prepared by the same procedure, except that dichloroacetyl chloride ( $48 \mu \mathrm{l}, 0.50 \mathrm{mmol})$ was used instead of chloroacetyl chloride.

Cell lines and culture. The human ovarian epidermoid cancer A431 cells were purchased from the American Type Culture Collection (Rockville, MD, USA). The human glioblastoma
U87MG cell line and its stable transfectants, expressing wild-type EGFR (U87MG.wtEGFR) or mutant $\triangle$ EGFR (U87MG. $\triangle E G F R)(15,16)$, were from the Cavanee laboratory, Ludwig Institute for Cancer Research (San Diego, USA). Cells were grown in Dulbecco's modified Eagle's medium (DMEM) containing $10 \%$ heat-inactivated fetal bovine serum, $100 \mathrm{U} / \mathrm{ml}$ penicillin and $100 \mu \mathrm{g} / \mathrm{ml}$ streptomycin in $5 \% \mathrm{CO}_{2}$ at $37^{\circ} \mathrm{C}$ in a humidified atmosphere.

Reagents and antibodies. The GM3 used for the biological analyses was purchased from Matreya Inc., (Pleasant Gap, PA, USA) and dissolved in chloroform/methanol $(\mathrm{C} / \mathrm{M} ; 2: 1)$ to make a stock solution $(1 \mathrm{mg} / \mathrm{ml})$. The antibodies used for western blotting were rabbit anti-EGFR monoclonal antibody (mAb; sc-03; Santa Cruz Biotechnology, Inc., Santa Cruz, CA, USA), rabbit anti-phospho-EGFR (PY1068) mAb (Epitomics, Burlingame, CA, USA) and mouse anti-GAPDH $\mathrm{mAb}$ (Millipore, Billerica, MA, USA).

EGFR activation assay. EGFR autophosphorylation and the effects of GM3 and the chloro-derivatives were analyzed as described previously (17). GM3, dichloro-GM3 and monochloro-GM3 in C/M (2:1) were dried completely under $\mathrm{N}_{2}$ stream. The dried gangliosides were added with serum-free DMEM and sonicated for $10 \mathrm{~min}$. The A431, U87MG.wtEGFR and U87MG. EGFR cells were cultured in 24-well plates until $\sim 90 \%$ confluency and starved in serum-free DMEM for $24 \mathrm{~h}$. The starved cells were incubated in serum-free DMEM containing GM3, dichloro-GM3 or monochloro-GM3 for $16 \mathrm{~h}$ at $37^{\circ} \mathrm{C}$. EGF $(100$ or $1 \mathrm{ng} / \mathrm{ml})$ was added to the culture media, and the cells were further incubated for $30 \mathrm{~min}$ at $37^{\circ} \mathrm{C}$. The cells were washed with Dulbecco's phosphate-buffered saline (PBS) containing $500 \mathrm{nM} \mathrm{Na}_{3} \mathrm{VO}_{4}, 5 \mathrm{mM}$ EDTA, $5 \mathrm{mM} \mathrm{NaF}$ and $10 \mathrm{mM} \mathrm{Na}_{4} \mathrm{O}_{7} \mathrm{P}_{2}$ and then lysed with $100 \mu \mathrm{L}$ radioimmunoprecipitation assay lysis buffer [1\% Nonidet P- $40,25 \mathrm{mM}$ Tris- $\mathrm{HCl}$ (pH 7.6), $150 \mathrm{mM} \mathrm{NaCl}, 1 \%$ deoxycholic acid and $0.1 \%$ SDS] containing $1 \%$ aprotinin, $1 \%$ phenylmethanesulfonyl fluoride, $500 \mathrm{nM} \mathrm{Na} \mathrm{VO}_{4}$ and Halt Protease and Phosphatase Inhibitor cocktail (Thermo Fisher Scientific, Inc., Waltham, MA, USA) for $30 \mathrm{~min}$ at $4^{\circ} \mathrm{C}$. The solutions were centrifuged at $13,225 \mathrm{x}$ g for $10 \mathrm{~min}$ at $4^{\circ} \mathrm{C}$, and the supernatants were collected and used as cell lysates. The protein concentration of the cell lysates was determined using a Micro Bicinchoninic Acid Protein Assay kit (Pierce Biotechnology, Inc., Rockford, IL, USA).

SDS-PAGE and western blot analysis. The cell lysates were analyzed by western blotting, as described previously (18-21). In brief, subsequent to boiling for $5 \mathrm{~min}$ at $98^{\circ} \mathrm{C}$ in SDS sample buffer, $5 \mu \mathrm{g}$ protein of each cell lysate was resolved by $7.5 \%$ SDS-PAGE and transferred onto polyvinylidene fluoride membranes (Thermo Fisher Scientific, Inc.). The membranes were blocked with $3 \%$ bovine serum albumin/Tris-buffered saline (TBS) containing 0.1\% Tween-20 (TBS-T) for $1 \mathrm{~h}$ at r.t., incubated with specific primary antibodies in TBS-T for $2 \mathrm{~h}$ at r.t. or overnight at $4^{\circ} \mathrm{C}$ and washed. The membranes were then incubated with appropriate secondary antibodies conjugated with horseradish peroxidase in TBS-T for $1 \mathrm{~h}$ at r.t. and washed 3 times with TBS-T. Detection was performed by enhanced chemiluminescence using SuperSignal West Pico 


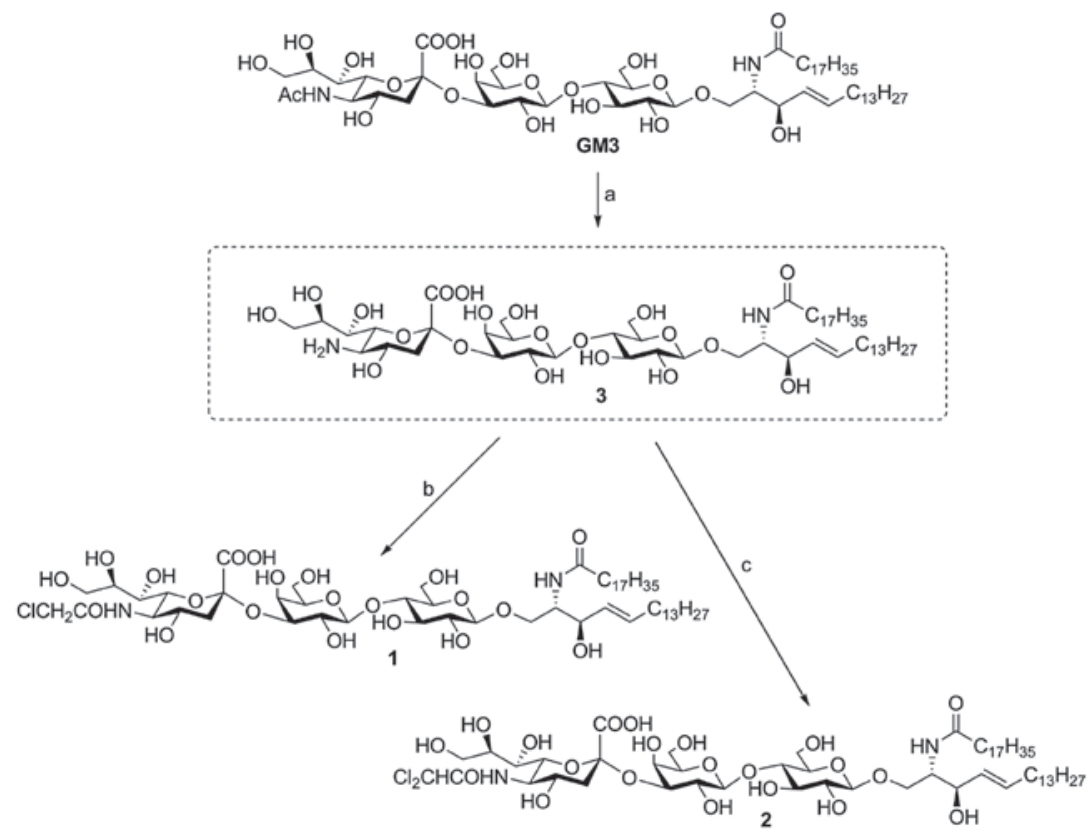

Figure 1. Method for synthesis of GM3 chloro-derivatives. Reagents and conditions: (A) $0.1 \mathrm{M} \mathrm{KOH}, 80^{\circ} \mathrm{C}, 5 \mathrm{~h} ;(\mathrm{B}) \mathrm{MeOH}_{2} \mathrm{CH}_{2} \mathrm{Cl}_{2}, \mathrm{Et}_{3} \mathrm{~N}, \mathrm{ClCH}_{2} \mathrm{COCl}_{\text {, }}$ r.t., 2 h, 49\% (two steps from GM3); (C) $\mathrm{MeOH}, \mathrm{CH}_{2} \mathrm{Cl}_{2}$, $\mathrm{Et}_{3} \mathrm{~N}, \mathrm{Cl}_{2} \mathrm{CHCOCl}$, r.t., 2 h, $26 \%$ (two steps from GM3). Compound 1, monochloro-GM3; and compound 2, dichloro-GM3. GM3, sialosyllactosylceramide.

chemiluminescent substrate (Thermo Fisher Scientific, Inc.). The intensity of western blotting was determined by densitometry using the ImageJ program (http://rsb.info.nih.gov/ij/).

$\left[{ }^{3} \mathrm{H}\right]$-thymidine cell incorporation assay. $\left[{ }^{3} \mathrm{H}\right]$-thymidine incorporation into DNA was used as a measure of the DNA replication level, following the method of Gabelman and Emerman (22). The A431, U87MG.wtEGFR and U87MG. $\triangle$ EGFR cells were cultured in 48-well plates in DMEM containing $10 \%$ fetal bovine serum until $70-80 \%$ confluence, and then starved in serum-free DMEM for $24 \mathrm{~h}$. The starved cells were incubated in serum-free DMEM containing GM3, monochloro-GM3 or dichloro-GM3 for $16 \mathrm{~h}$ at $37^{\circ} \mathrm{C}$. EGF (100 or $1 \mathrm{ng} / \mathrm{ml}$ ) was added to the culture media and the cells were further incubated for 2 or $24 \mathrm{~h}$ at $37^{\circ} \mathrm{C}$. The cells were then incubated with $0.8 \mu \mathrm{Ci}$ of $\left[{ }^{3} \mathrm{H}\right]$-thymidine (PerkinElmer, Waltham, MA, USA) for $4 \mathrm{~h}$ at $37^{\circ} \mathrm{C}$, washed 3 times with PBS and detached with trypsin/EDTA. The cell suspension was mixed with Ecoscint (1:30; National Diagnostics, Atlanta, GA, USA), and $\left[{ }^{3} \mathrm{H}\right]$-thymidine incorporation was determined by a liquid scintillation $\beta$-counter (Beckman Instruments, Fullerton, CA, USA).

Statistical analysis. The data were analyzed by Student's t-test. $\mathrm{P} \leq 0.05$ was considered to indicate a statistically significant difference.

\section{Results}

Synthesis of GM3 chloro-derivatives. GM3 was synthesized, as described previously (11), at the Institute of Paris Molecular Chemistry(UniversityPierre\&MarieCurieParis6,Paris,France). A suitably protected lactoside diol was glycosylated with sialyl xanthate to exclusively produce the $\alpha$-sialyl trisaccharide at a good yield based on a highly stereoselective and regioselective sialylation. Following chemical modification, this trisaccharide was reacted with 3-O-benzoylated azidosphingosine to form a GSL, which subsequent to a reduction of azide followed by condensation with stearic acid and deprotection, yielded GM3.

Under strongly basic conditions $\left(0.1 \mathrm{M} \mathrm{KOH}, 80^{\circ} \mathrm{C}\right)$, the $N$-acetyl group of GM3 was hydrolyzed to yield the key intermediate 3 (Fig. 1), in which the free amino functionality could be subjected to derivatization. Two $N$-modified GM3 analogues, compound 1 (monochloro-GM3) and compound 2 (dichloro-GM3) (Fig. 1), were synthesized from intermediate 3.

Compound 1 was obtained (14.9 mg, $49 \%$ for two steps) as a white foam with a retention factor ( $\mathrm{Rf}$ ) value of 0.45 $\left(\right.$ EtOAc-iPrOH- $\left.\mathrm{H}_{2} \mathrm{O}, 3: 2: 1\right)$ and an $[\alpha]_{\mathrm{D}}$ of -0.3 (c, 0.5; and $\left.\mathrm{CHCl}_{3}: \mathrm{MeOH}, 1: 1\right)$. The NMR spectral data were in good agreement with results reported previously (23). The ESI-HRMS (m/z) for $\mathrm{C}_{59} \mathrm{H}_{106} \mathrm{ClN}_{2} \mathrm{O}_{21}[\mathrm{M}-\mathrm{H}]^{-}$was calculated as $1213.6982 \mathrm{~m} / \mathrm{z}$ and found to be $1213.7015 \mathrm{~m} / \mathrm{z}$.

Compound 2 was obtained $(8.1 \mathrm{mg}, 26 \%$ for two steps $)$ as a white foam, with an Rf of 0.53 (EtOAc-iPrOH- $\mathrm{H}_{2} \mathrm{O}, 3: 2: 1$ ); and $a n[\alpha]_{\mathrm{D}}$ of -0.4 (c, 0.5 ; and $\left.\mathrm{CHCl}_{3}: \mathrm{MeOH}, 1: 1\right) .{ }^{1} \mathrm{H}$ NMR (400 MHz; $\left.\mathrm{CDCl}_{3}: \mathrm{CD}_{3} \mathrm{OD}, 1: 1\right): \delta 6.16$ [singlet (s), $1 \mathrm{H}, \mathrm{Cl}_{2} \mathrm{CH}$ ], 5.63 [triple doublet $(\mathrm{td})$, coupling constants $(\mathrm{J})=15.0,6.8 \mathrm{~Hz}$, $1 \mathrm{H}, \mathrm{H}-5$ cer], 5.38 [double doublet (dd), J=15.3, 7.6 Hz, 1H, H-4cer], 4.36 (d, J=7.8 Hz, 1H, H-1Gal), 4.24 (d, J=7.8 Hz, 1H, H-1Glu), 4.14 (dd, J=9.9, 4.0 Hz, 1H, Ha-1cer), 4.04 (dd, J=8.5, 5.9 Hz, 1H, H-3cer), 4.01-3.89 [multiplet (m), 3H, H-3Gal, H-2cer, H-4Gal], 3.89-3.78 (m, 4H, Ha-6Gal, Hb-6Gal, Ha-6Glu, H-6Neu), 3.77-3.68 (m, 4H, Ha-9Neu, H-4Neu, H-5Neu, H-5Gal), 3.66-3.46 (m, 7H, Hb-6Glu, H-5Glu, Hb-9Neu, H-8Neu, H-2Gal, H-3Glu, H-4Glu), 3.44 (d, J=9.0 Hz, 1H, Hb-1cer), 3.40-3.34 (m, 1H, H-7Neu), 3.24 (d, J=10.2 Hz, 1H, H-2Glu), 2.88-2.67 (m, $1 \mathrm{H}, \mathrm{Heq}-3 \mathrm{Neu}$ ), 2.11 [triplet (t), J=7.6 Hz, 2H, $\mathrm{CH}_{2} \mathrm{C}(\mathrm{O})$ ], 1.96 (dd, J=12.7, $5.8 \mathrm{~Hz}, 2 \mathrm{H}, \mathrm{H} 2-6 \mathrm{cer}), 1.76-1.66$ (m, $1 \mathrm{H}$, Hax-3Neu), 1.56-1.48 (m, 2H, $\mathrm{CH}_{2} \mathrm{CH}_{2} \mathrm{C}(\mathrm{O})$ ), 1.25-1.19 (m, 
A
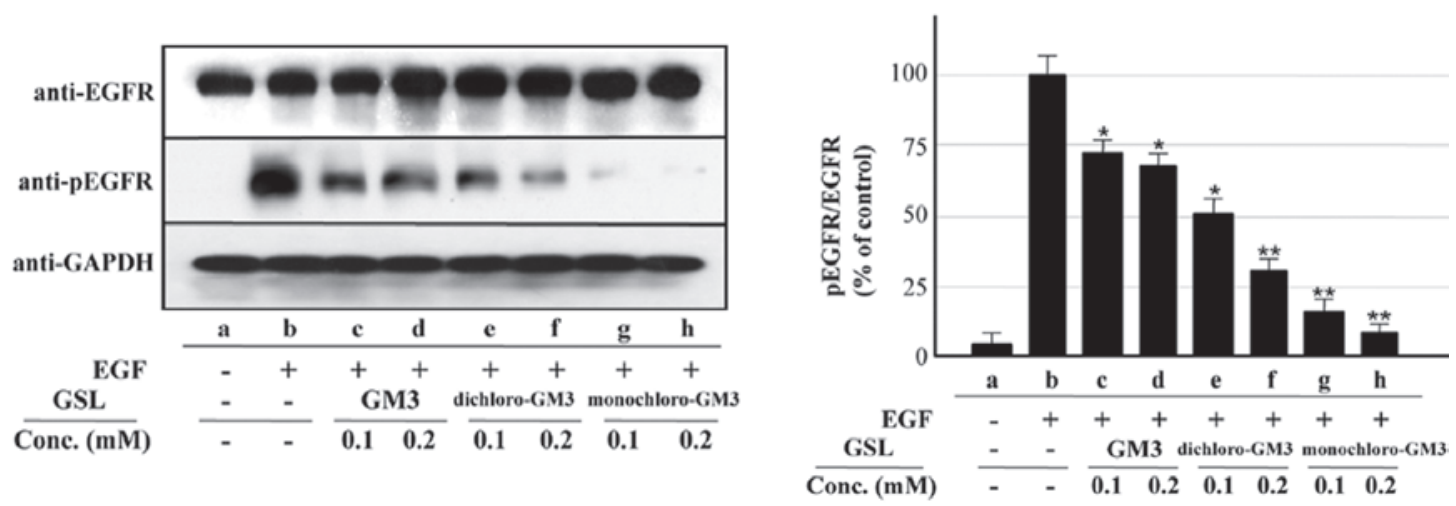

B
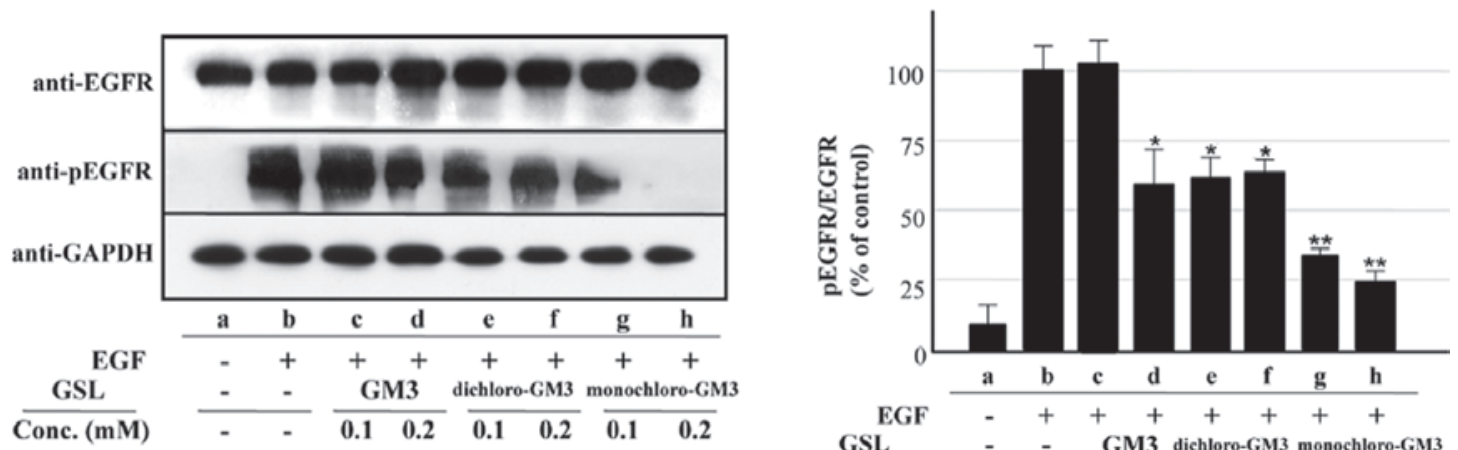

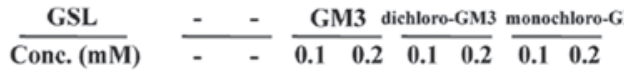

C
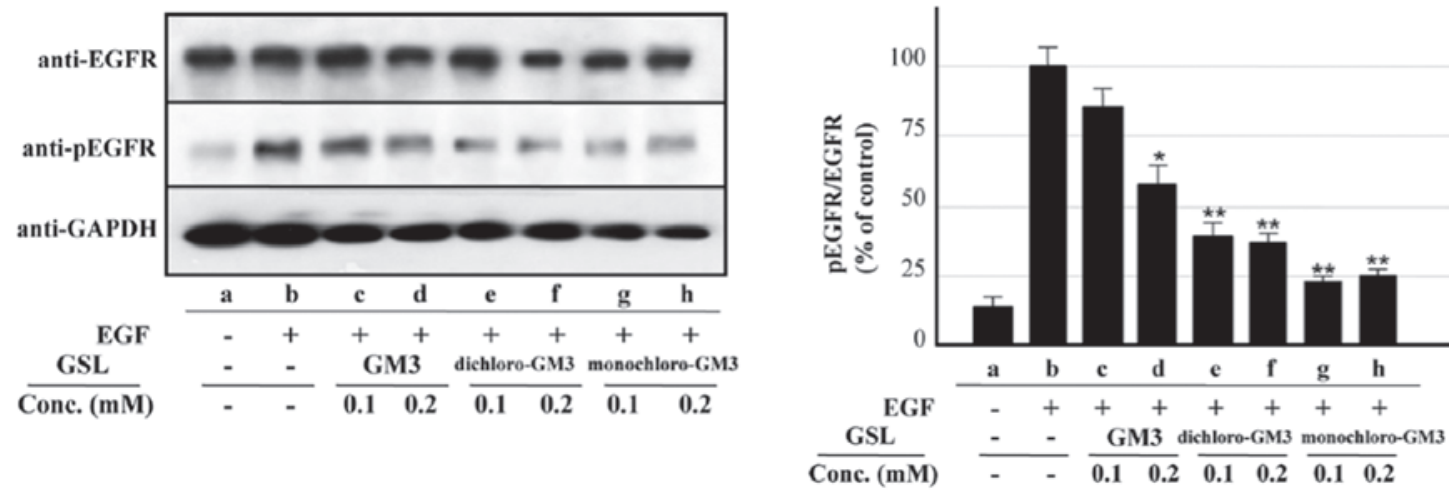

D
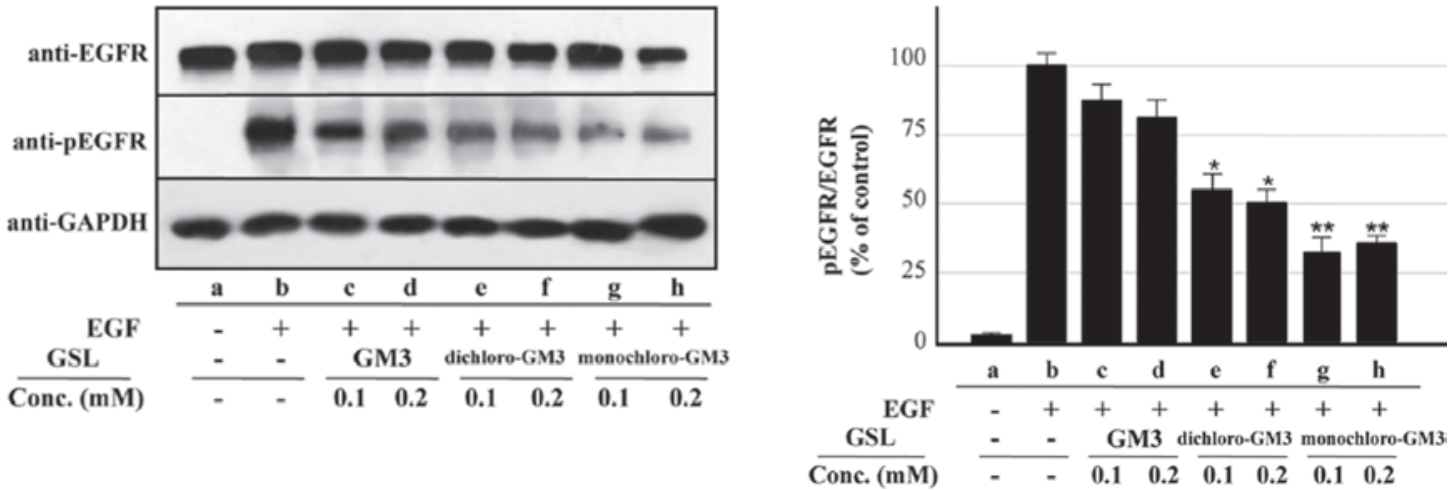

Figure 2. Inhibitory effects of pre-incubation with GM3, monochloro-GM3 and dichloro-GM3 on EGFR activation (autophosphorylation) in the A431, U87MG.wtEGFR and U87MG.AEGFR cells. (A) A431 cells, $100 \mathrm{ng} / \mathrm{ml}$ EGF. (B) A431 cells, $1 \mathrm{ng} / \mathrm{ml}$ EGF. (C) U87MG.wtEGFR cells, $100 \mathrm{ng} / \mathrm{ml}$ EGF. (D) U87MG.wtEGFR cells, $1 \mathrm{ng} / \mathrm{ml}$ EGF. Left, representative western blotting results from triplicate experiments. GAPDH signals are shown to confirm the protein amounts in the cell lysates. Right, the y-axis indicates the ratio of phosphorylated EGFR (pEGFR) to EGFR as a percentage of the control value. The control is $b$ in panels A-F and a in panel G. The results are presented as the mean \pm standard deviation. " $\mathrm{P}<0.05 ;{ }^{* *} \mathrm{P}<0.01$. GM3, sialosyllactosylceramide; EGFR, epidermal growth factor receptor; GSL, glycosphingolipids. 


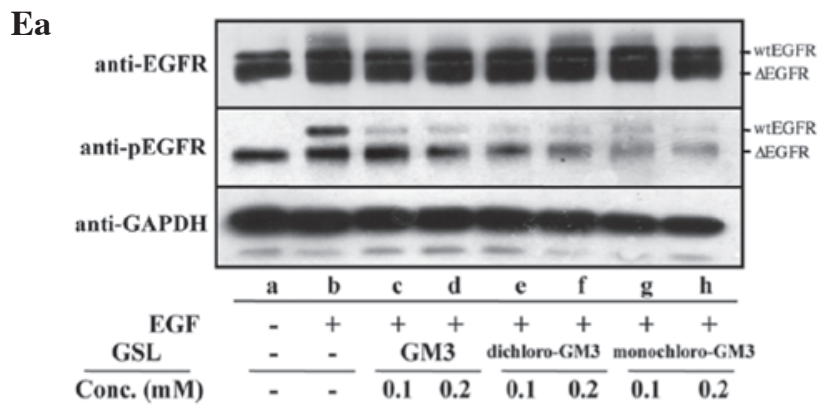

Eb

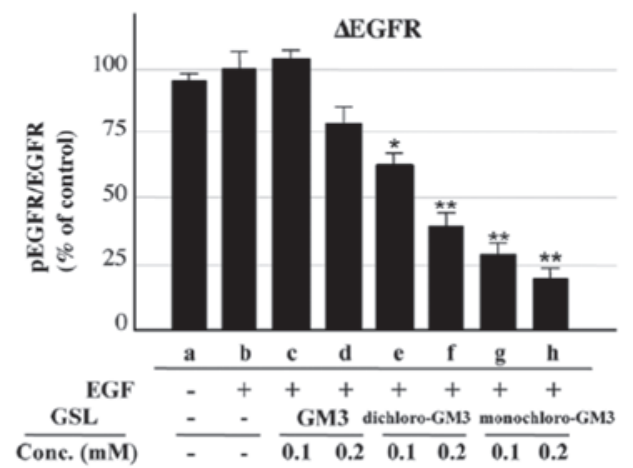

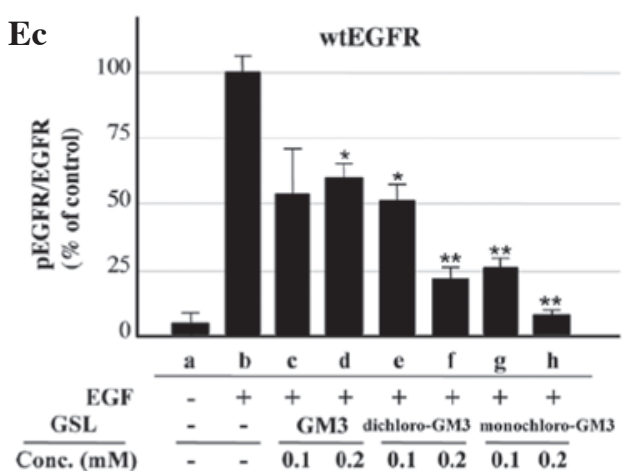

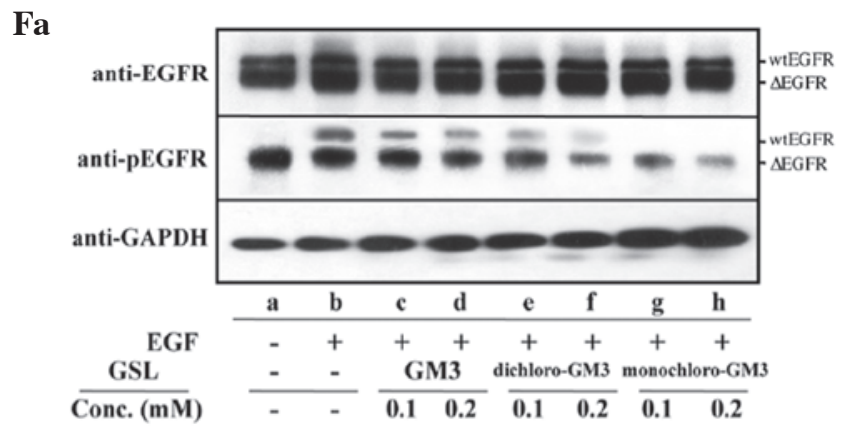

$\mathbf{F b}$
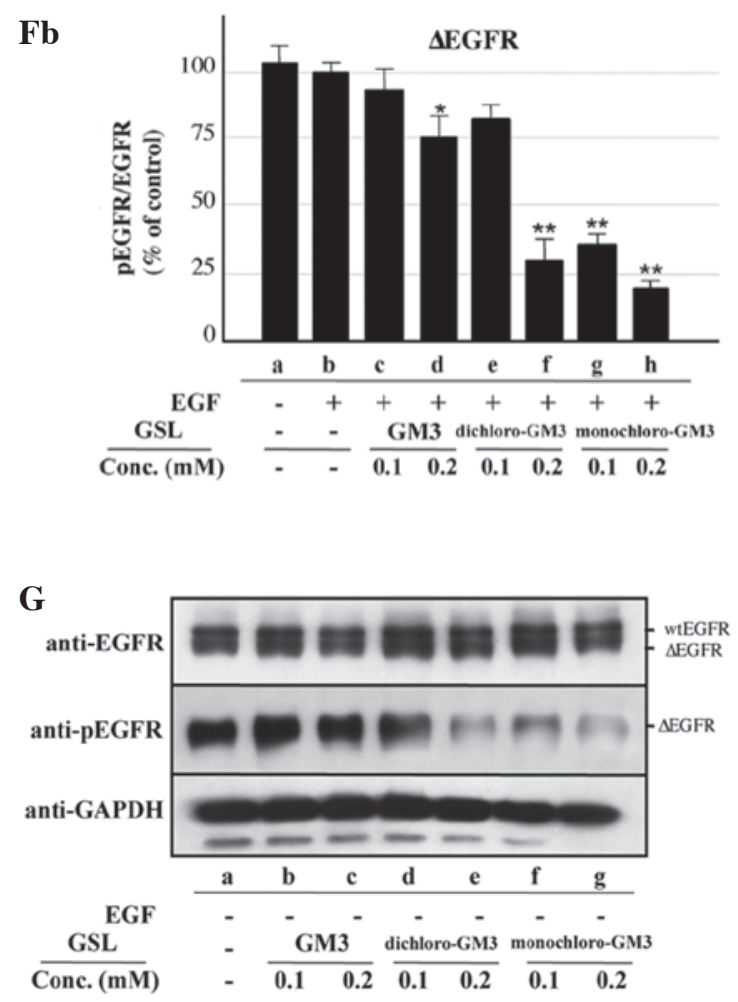
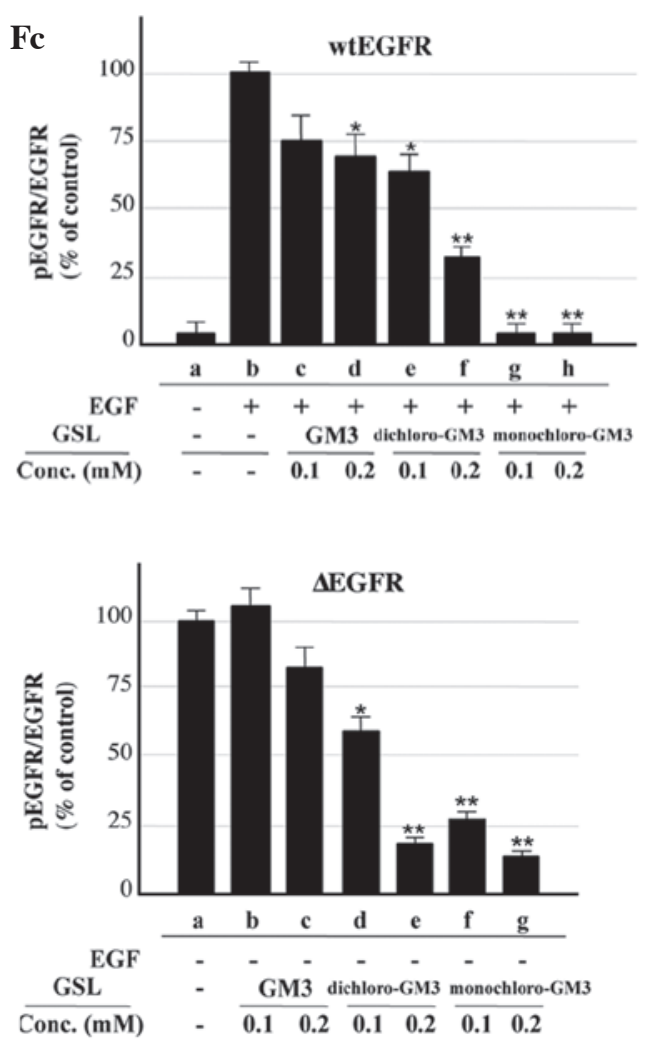

Figure 2. Continued. (E) U87MG. $\Delta$ EGFR cells, $100 \mathrm{ng} / \mathrm{ml}$ EGF. (F) U87MG. $\Delta$ EGFR cells, $1 \mathrm{ng} / \mathrm{ml}$ EGF. (G) U87MG. $\Delta$ EGFR cells, no EGF. The results are presented as the mean \pm dtandard deviation. ${ }^{*} \mathrm{P}<0.05 ;{ }^{* * *} \mathrm{P}<0.01$. GM3, sialosyllactosylceramide; EGFR, epidermal growth factor receptor; GSL, glycosphingolipids. 
$50 \mathrm{H}$, alkane $\left.\mathrm{CH}_{2}\right)$ and $0.82\left(\mathrm{t}, \mathrm{J}=6.8 \mathrm{~Hz}, 6 \mathrm{H}, 2 \mathrm{xCH}_{3}\right)$. ${ }^{13} \mathrm{C} \mathrm{NMR}\left(100 \mathrm{MHz} ; \mathrm{CDCl}_{3}: \mathrm{CD}_{3} \mathrm{OD}, 1: 1\right): \delta 134.92$ (C-5cer), 130.25 (C-4cer), 104.48 (C-1Gal), 103.73 (C-1Glu), 80.36, 76.95, 76.21, 75.66, 75.39, 74.05, 73.95, 72.51, 72.37, 70.10, 69.42 (C-1cer), 68.43, 68.31, $66.94\left(\mathrm{Cl}_{2} \mathrm{CH}\right), 64.05,63.91$, 62.25, 61.18, 53.99 (C-2cer), 53.74 (C-5Neu), 41.30 (C-3cer), $37.04,33.01,32.53,30.31,30.24,30.22$, 30.12, 29.97, 29.91, 26.64, 23.24 and $14.34\left(2 \mathrm{xCH}_{3}\right)$. ESI-HRMS $(\mathrm{m} / \mathrm{z})$ for $\mathrm{C}_{59} \mathrm{H}_{105} \mathrm{Cl}_{2} \mathrm{~N}_{2} \mathrm{O}_{21}[\mathrm{M}-\mathrm{H}]^{-}$was calculated as $1247.6592 \mathrm{~m} / \mathrm{z}$ and found to be $1247.6595 \mathrm{~m} / \mathrm{z}$.

Inhibitory effect of GM3 chloro-derivatives on EGFR activation. The inhibitory effects of monochloro- and dichloro-GM3 on EGF-induced EGFR activation were evaluated and compared with that of GM3 using A431 cells, which express a high level of EGFR at the cell surface. In agreement with the findings of our previous studies $(3,4,18,19,24)$, pre-incubation of the cells with GM3 at either 0.1 or $0.2 \mathrm{mM}$ caused $\sim 65 \%$ inhibition of EGFR activation (as assessed by its autophosphorylation) induced by $100 \mathrm{ng} / \mathrm{ml} \mathrm{EGF}$ (Fig. 2A, columns c and d). The degree of inhibition by the chloro-derivatives at concentrations of 0.1 and $0.2 \mathrm{mM}$ was $\sim 50$ and $\sim 70 \%$ for dichloro-GM3 (Fig. 2A, columns e and f) and $\sim 85$ and $\sim 90 \%$ for monochloro-GM3 (Fig. 2A, columns $\mathrm{g}$ and $\mathrm{h}$ ), respectively. For EGFR activation induced by $1 \mathrm{ng} / \mathrm{ml}$ EGF, $0.2 \mathrm{mM}$ GM3 caused $40 \%$ inhibition and $0.1 \mathrm{mM}$ GM3 exhibited no significant effect (Fig. 2B, columns $\mathrm{c}$ and $\mathrm{d}$ ). The degree of inhibition at concentrations of 0.1 and $0.2 \mathrm{mM}$ was $\sim 37$ and $\sim 32 \%$ for dichloro-GM3 (Fig. 2B, columns e and f) and $\sim 65$ and $\sim 75 \%$ for monochloro-GM3 (Fig. 2B, columns g and h), respectively. The inhibitory effects of GM3 and the chloro-derivatives on EGFR activation in the U87MG.wtEGFR cells were quite similar for EGF concentrations of 100 (Fig. 2C, columns c-h) and $1 \mathrm{ng} / \mathrm{ml}$ (Fig. 2D, columns c-h).

The inhibitory effects of GM3 and its chloro-derivatives were also evaluated in U87MG. $\mathrm{EGGR}$ cells, which overexpress the highly oncogenic mutant $\triangle E G F R$ gene, a commonly occurring variant of EGFR that lacks exons 2-7 $(25,26)$. These exons code for the $\mathrm{N}$-terminal region that includes the EGF binding site, and the deleted form of EGFR is therefore constitutively autophosphorylated without EGF stimulation in U87MG. $\mathrm{EEGFR}$ cells $(15,16)$. In the present study, two types of EGFR (endogenous wtEGFR and transfected $\triangle E G F R$ ) were detected in these cells as expected, and $\triangle E G F R$ autophosphorylation was detected at similar levels regardless of the presence or absence of EGF. In contrast to the results for wtEGFR, $\triangle E G F R$ autophosphorylation was not significantly inhibited by $0.1 \mathrm{mM} \mathrm{GM}$, but was $\sim 25 \%$ inhibited by $0.2 \mathrm{mM} \mathrm{GM} 3$ at 100 (Fig. 2Eb, columns b-d) and $1 \mathrm{ng} / \mathrm{ml}$ EGF (Fig. 2Fb, columns b-d). The chloro-derivatives showed notable inhibitory effects under all three conditions: 100 ng/ml EGF (Fig. 2E), 1 ng/ml EGF (Fig. 2F) and no EGF (Fig. 2G). Monochloro-GM3 produced $\sim 73$ and $\sim 80 \%$ inhibition at concentrations of 0.1 and $0.2 \mathrm{mM}$, respectively (Fig. 2Eb and Fb, columns b, g and h; Fig. 2G, columns a, f and $\mathrm{g}$ ). The inhibitory effects of dichloro-GM3 were stronger than those of GM3, but less than those of monochloro-GM3 (Fig. 2E-G). The inhibitory effects of GM3 and the chloro-derivatives on endogenous wtEGFR expressed in the U87MG. $\triangle E$ EFR cells were extremely similar to those observed for the A431 and U87MG.wtEGFR cells (Fig. 2Ec and Fc).

Inhibitory effects of GM3 and its chloro-derivatives on cell proliferation. The inhibitory effects of GM3 and its chloro-derivatives on cell proliteration were analyzed by the $\left[{ }^{3} \mathrm{H}\right]$-thymidine incorporation assay. Treatment with EGF at $100 \mathrm{ng} / \mathrm{ml}$, the concentration used for analysis of EGFR activation in the A431 cells, inhibited rather than promoted cell proliferation (data not shown). As indicated in our previous study (24), this result may be due to the excessive expression of EGFR on the surface of the A431 cells. As $1 \mathrm{ng} / \mathrm{ml}$ EGF induced cell proliferation (Fig. 3B, columns a and b), this concentration was used for the analysis of the inhibitory effects of GM3 and the chloro-derivatives. The chloro-derivatives, particularly monochloro-GM3, significantly inhibited $\left[{ }^{3} \mathrm{H}\right]$-thymidine incorporation into the A431 cells (Fig. 3A and B, columns b, e-h), whereas GM3 showed an enhancing effect (Fig. 3A and B, columns b-d). The mechanism of this enhancing effect remains unclear, but it may be associated with the excessive expression of EGFR on the surface of the A431 cells, as aforementioned. Similar inhibitory effects of the chloro-derivatives were observed in the U87MG.wtEGFR cells at the EGF concentrations used (Fig. 3C and D, columns a-h). The chloro-derivatives significantly inhibited $\left[{ }^{3} \mathrm{H}\right]$-thymidine incorporation into the U87MG. $\triangle E$ EFR cells in the presence and absence of EGF, whereas GM3 exhibited no significant inhibitory effect (Fig. 3E and F, columns a-h; Fig. 3G, columns a-g). These findings were consistent with those from the analysis of $\triangle E G F R$ autophosphorylation, as described in the preceding section.

\section{Discussion}

The expression of glycosyl epitopes, carried as glycoproteins or GSLs on the surface of mammalian cells, is known to vary quantitatively and qualitatively in association with various cell phenotypes. GM3, a sialic acid-containing GSL whose expression is reduced in transformed cells, inhibits EGFR activation, a process associated with cancer cell growth and motility (4).

Studies utilizing synthetic molecules that resemble natural GSLs provide important information that is not available from studies utilizing molecules from natural sources. In the present study, to elucidate the inhibitory effects of the chloro-derivatives of GM3 on EGFR activation, a simple and efficient synthetic route was developed for the preparation of monochloro- and dichloro-GM3. The key step is a highly regioselective and stereoselective sialylation from a suitably protected lactoside diol with a sialyl xanthate, to exclusively provide the $\alpha$-sialyl trisaccharide at a good yield. Selective hydrolysis of the $\mathrm{N}$-acetyl group of GM3 was achieved under basic conditions $\left(0.1 \mathrm{M} \mathrm{KOH}, 80^{\circ} \mathrm{C}\right)$ to yield key intermediate 3 (Fig. 1), from which the two chloro-derivatives were prepared.

The finding that two halogen-(chloro-) derivatives of GM3 have stronger inhibitory effects on EGFR activation than GM3, indicates that the chemical synthesis approach described in the present study can be applied for the development of more potent inhibitors. The effects of trichloro-derivatives and fluoro-derivatives of GM3 should also be evaluated. It is 
A

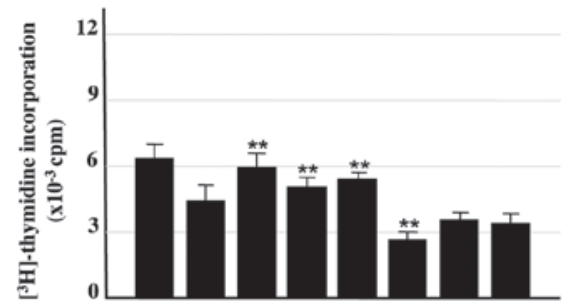

C

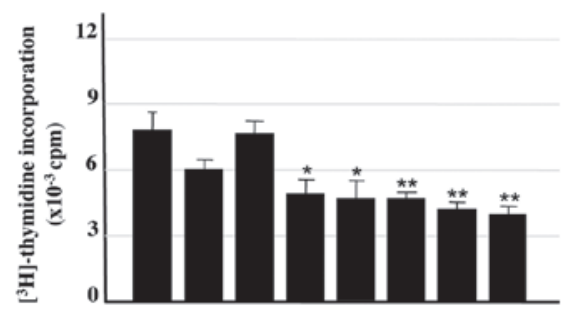

$\mathbf{E}$

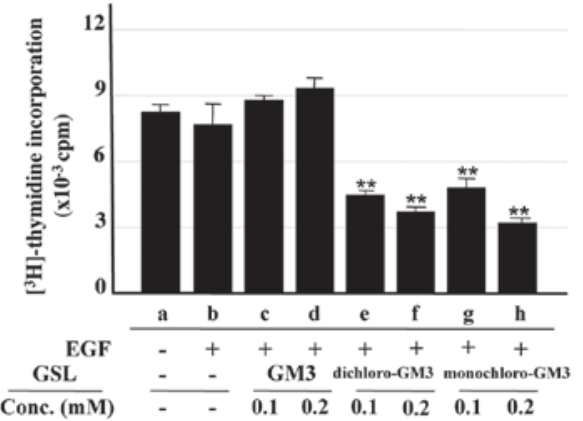

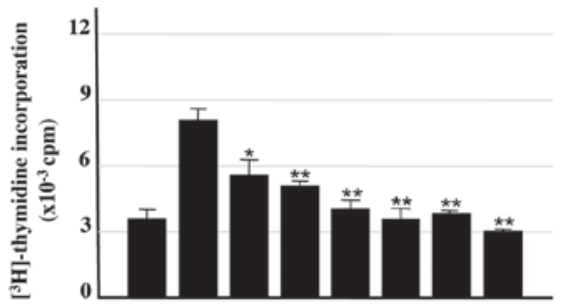

D

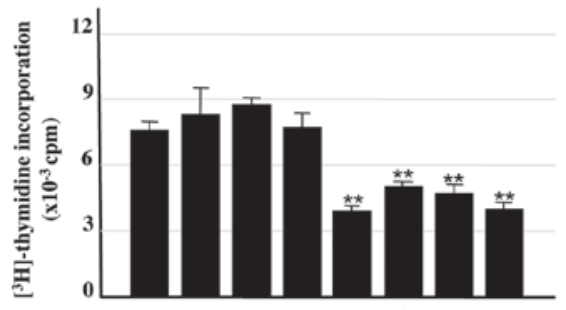

$\mathbf{F}$

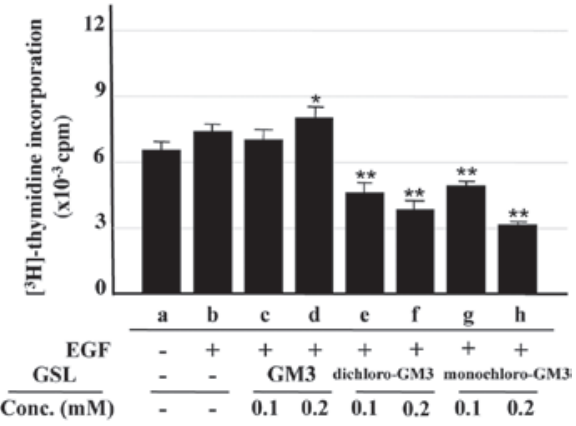

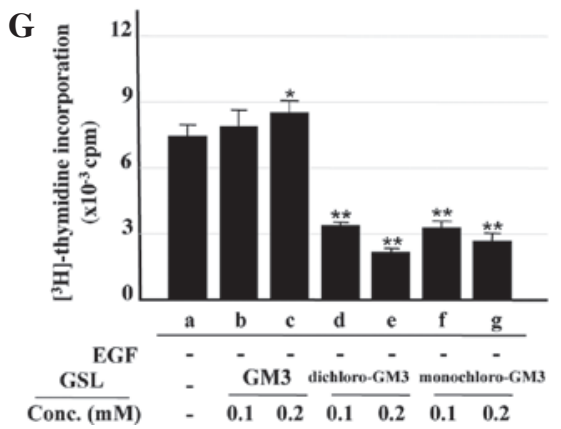

Figure 3. Inhibitory effects of GM3, monochloro-GM3 and dichloro-GM3 on cell proliferation, assessed by [ $\left.{ }^{3} \mathrm{H}\right]$-thymidine incorporation assay. (A) A431 cells, $100 \mathrm{ng} / \mathrm{ml} \mathrm{EGF}$. (B) A431 cells, $1 \mathrm{ng} / \mathrm{ml}$ EGF. (C) U87MG.wtEGFR cells, $100 \mathrm{ng} / \mathrm{ml}$ EGF. (D) U87MG.wtEGFR cells, $1 \mathrm{ng} / \mathrm{ml} \mathrm{EGF.} \mathrm{(E)} \mathrm{U87MG.} 4$ EGFR cells, $100 \mathrm{ng} / \mathrm{ml}$ EGF. (F) U87MG. $\triangle$ EGFR cells, $1 \mathrm{ng} / \mathrm{ml}$ EGF. (G) U87MG. $\mathrm{EGFR}$ cells, no EGF. $\left[{ }^{3} \mathrm{H}\right]$-thymidine incorporation was expressed as cpm. All experiments were performed in triplicate and results are presented as the mean \pm standard deviation. The control is $\mathrm{b}$ in panels A-F and a in panel G. ${ }^{*} \mathrm{P}<0.05$; ${ }^{* *} \mathrm{P}<0.01$. GM3, sialosyllactosylceramide; EGF, epidermal growth factor; GSL, glycosphingolipids; cpm, counts per minute.

noteworthy that monochloro-GM3 inhibited the activation of $\triangle \mathrm{EGFR}$, which is commonly expressed in glioblastomas (the most aggressive type of brain tumor in humans) and whose continuous EGF-independent activation is associated with greatly enhanced malignant behavior. The inhibitory effects of the two chloro-derivatives on EGFR activation (autophosphorylation) and cell proliferation $\left(\left[{ }^{3} \mathrm{H}\right]\right.$-thymidine incorporation) were stronger than that of GM3. Monochloro-GM3 also exhibited a significant inhibitory effect on $\triangle \mathrm{EGFR}$, which is a mutant form of EGFR often found in glioblastomas.

Our previous studies have shown that: (i) GM3 inhibits EGFR activation through carbohydrate-to-carbohydrate interaction; (ii) GM3 interacts with $N$-linked glycans carrying multiple GlcNAc termini carried by EGFR; and (iii) such interaction is the molecular mechanism whereby GM3 inhibits EGFR activation $(18,19)$. Studies are in progress to determine whether monochloro- and dichloro-GM3 bind more strongly than GM3 to $N$-linked glycans carrying multiple GlcNAc termini.

The chemical synthesis of other GM3 derivatives using approaches similar to that described in the present study has the potential to create more potent EGFR inhibitors.

\section{Acknowledgements}

The present study was funded by the Université Pierre et Marie Curie-Paris 6 for the program of LIA, The Biomembrane Institute and P01-CA95616. Support was also accorded by a PhD fellowship from the China Scholarship Council. The authors are grateful to Dr S. Anderson for editing the English of the manuscript. 


\section{References}

1. Hakomori S: Tumor malignancy defined by aberrant glycosylation and sphingo(glyco)lipid metabolism. Cancer Res 56: 5309-5318, 1996.

2. Bremer EG and Hakomori S: GM3 ganglioside induces hamster fibroblast growth inhibition in chemically-defined medium: ganglioside may regulate growth factor receptor function. Biochem Biophys Res Commun 106: 711-718, 1982.

3. Bremer EG, Hakomori S, Bowen-Pope DF, Raines E and Ross R: Ganglioside-mediated modulation of cell growth, growth factor binding, and receptor phosphorylation. J Biol Chem 259: 6818-6825, 1984.

4. BremerEG,SchlessingerJ and HakomoriS: Ganglioside-mediated modulation of cell growth. Specific effects of GM3 on tyrosine phosphorylation of the epidermal growth factor receptor. J Biol Chem 261: 2434-2440, 1986.

5. Miljan EA, Meuillet EJ, Mania-Farnell B, et al: Interaction of the extracellular domain of the epidermal growth factor receptor with gangliosides. J Biol Chem 277: 10108-10113, 2002.

6. Noll EN, Lin J, Nakatsuji Y, Miller RH and Black PM: GM3 as a novel growth regulator for human gliomas. Exp Neurol 168 : 300-309, 2001

7. Nakatsuji Y and Miller RH: Selective cell-cycle arrest and induction of apoptosis in proliferating neural cells by ganglioside GM3. Exp Neurol 168: 290-299, 2001.

8. Hakomori S, Young WW Jr, Patt LM, Yoshino T, Halfpap L and Lingwood CA: Cell biological and immunological significance of ganglioside changes associated with transformation. Adv Exp Med Biol 125: 247-261, 1980

9. Nishikawa R, Ji XD, Harmon RC, et al: A mutant epidermal growth factor receptor common in human glioma confers enhanced tumorigenicity. Proc Natl Acad Sci USA 91: 7727-7731, 1994.

10. Furnari FB, Fenton T, Bachoo RM, et al: Malignant astrocytic glioma: genetics, biology, and paths to treatment. Genes Dev 21: 2683-2710, 2007.

11. Zhu ZY and Zhang YM: An efficient method for ganglioside GM3 preparation. Acta Chim Sinica 65: 2909-2916, 2007 (In Chinese).

12. Tanaka H, Adachi $\mathrm{M}$ and Takahashi T: One-pot synthesis of sialo-containing glycosyl amino acids by use of an $\mathrm{N}$-trichloroethoxycarbonyl-beta-thiophenyl sialoside. Chemistry 11: 849-862, 2005.

13. Lin CC, Adak AK, Horng JC and Lin CC: Phosphite-based sialic acid donors in the synthesis of $\alpha(2 \rightarrow 9)$ oligosialic acids Tetrahedron 65: 4714-4725, 2009.

14. Byramova NE, Tuzikov AB and Bovin NV: Studies on the synthesis of sialosides and sialic acid analogs. 2. A simple procedure for the synthesis of the methyl and benzyl glycosides of Neu5Ac and 4-epi-Neu5Ac - Conversion of the benzyl and methyl glycosides of Neu5Ac into N-trifluoroacetylneuraminic acid benzyl glycosides. Carbohydr Res 237: 161-175, 1992.
15. Fernandes H, Cohen S and Bishayee S: Glycosylation-induced conformational modification positively regulates receptor-receptor association: a study with an aberrant epidermal growth factor receptor (EGFRvIII/DeltaEGRF) expressed in cancer cells. J Biol Chem 276: 5375-5383, 2001

16. Huang HS, Nagane M, Klingbeil CK, et al: The enhanced tumorigenic activity of a mutant epidermal growth factor receptor common in human cancers is mediated by threshold levels of constitutive tyrosine phosphorylation and unattenuated signaling. J Biol Chem 272: 2927-2935, 1997.

17. Zhou Q, Hakomori S, Kitamura K and Igarashi Y: GM3 directly inhibits tyrosine phosphorylation and de-N-acetyl-GM3 directly enhances serine phosphorylation of epidermal growth factor receptor, independently of receptor-receptor interaction. J Biol Chem 269: 1959-1965, 1994.

18. Yoon SJ, Nakayama K, Hikita T, Handa K and Hakomori SI: Epidermal growth factor receptor tyrosine kinase is modulated by GM3 interaction with N-linked GlcNAc termini of the receptor. Proc Natl Acad Sci USA 103: 18987-18991, 2006.

19. Kawashima N, Yoon SJ, Itoh K and Nakayama K: Tyrosine kinase activity of epidermal growth factor receptor is regulated by GM3 binding through carbohydrate to carbohydrate interactions. J Biol Chem 284: 6147-6155, 2009.

20. Todeschini AR, Dos Santos JN, Handa K and Hakomori S: Ganglioside GM2-tetraspanin CD82 complex inhibits met and its cross-talk with integrins, providing a basis for control of cell motility through glycosynapse. J Biol Chem 282: 8123-8133, 2007.

21. Mitsuzuka K, Handa K, Satoh M, Arai Y and Hakomori S: A specific microdomain ("glycosynapse 3") controls phenotypic conversion and reversion of bladder cancer cells through GM3-mediated interaction of alpha3beta1 integrin with CD9. J Biol Chem 280: 35545-34553, 2005.

22. Gabelman BM and Emerman JT: Effects of estrogen, epidermal growth factor, and transforming growth factor-alpha on the growth of human breast epithelial cells in primary culture. Exp Cell Res 201: 113-118, 1992.

23. Zheng M and Ye XS: Synthesis of N-modified ganglioside GM3 derivatives. Tetrahedron 68: 1475-1482, 2012.

24. Hanai N, Nores GA, MacLeod C, Torres-Mendez CR and Hakomori S: Ganglioside-mediated modulation of cell growth. Specific effects of GM3 and lyso-GM3 in tyrosine phosphorylation of the epidermal growth factor receptor. J Biol Chem 263: 10915-10921, 1988.

25. Ekstrand AJ, Sugawa N, James CD and Collins VP: Amplified and rearranged epidermal growth factor receptor genes in human glioblastomas reveal deletions of sequences encoding portions of the N-and/or C-terminal tails. Proc Natl Acad Sci USA 89: 4309-4313, 1992.

26. Sugawa N, Ekstrand AJ, James CD and Collins VP: Identical splicing of aberrant epidermal growth factor receptor transcripts from amplified rearranged genes in human glioblastomas. Proc Natl Acad Sci USA 87: 8602-8606, 1990. 